\title{
Low-head hydropower energy resource harvesting: design and manufacturing of the (HyPER) harvester
}

- Nadipuram R. Prasad

- Satish J. Ranade

New Mexico State University, Las Cruces, New Mexico, USA.

- Nguyen Huu Phuc

Ho Chi Minh city University of Technology, VNU-HCM, Vietnam.

(Manuscript Received on July 15, 2015, Manuscript Revised August 30, 2015)

\begin{abstract}
The design and manufacturing of a deploy to produce the desired power. A revolutionary hydropower harvester with characteristics that embrace the ecology and the environment is described. Guided by NEPA standards for environmental protection, the design concept incorporates a modular and self-supporting structure with a vertical-axis turbine-generator system that is: a) fabricated using Fiberglass and Carboncomposites and is light weight, and b) is easy to manufacture and assemble utilizing offthe-shelf electromechanical components and computational fluid dynamics (CFD) software, ANSYS $\odot$, is used to optimize the flow characteristics of the harvester. A fullyscalable, modular and easily deployable hydropower generating system prototype of a 10kW low-head hydropower harvester with 4blade fixed-pitch impeller is presented. The technology is adaptable for low-head drops along irrigation canals with existing structures and as modular weirs across small rivers and streams worldwide.
\end{abstract}

Keywords: computational fluid dynamics, harvester system, low-head Venturi turbine, turbine impellers.

\section{INTRODUCTION}

As a cause and effect phenomena, the misuse of natural hydropower resources and the irreversible damage to the ecology, strongly direct the imaginations and creativity of engineers and scientists to focus on technologies that will allow future generations to coexist in energy-efficient, self-sufficient, energy conserving, and selfsustaining environments. In Vietnam, for example, as much as $40 \%$ of electric power comes

from hydropower plants. The annual rate of growth in energy demand is expected to grow at a staggering rate of $15 \%$ per year. As such, many new hydropower installations are planned all across major rivers and their tributaries. More than 200 small-to-medium size plants have been approved for construction by the year 2020 . Numerous study reports and news articles document the consequence of dams and other ill- 
conceived use of hydropower resources in the Central Province and the Mekong River Delta, in neighboring Laos and Cambodia, especially in the Lower Sesan region of Cambodia and the Upper Sesan Region in Vietnam. A report entitled "Basin Profile of the Upper Sesan in Vietnam" captures the full spectrum of hydropower issues in the Central Province. Despite these concerns, large-, medium- and small-sized hydro power plants are being built rapidly on any power-potential river flow system. In all cases, the natural flow characteristics have been significantly altered, laying waste to the ecology and the environment with unprecedented impact on local economies and the whole Region. Figure 1 shows a diversion canal built across the Se Re Pok River (alt. Srepok) that diverts flow to a 280 MW hydropower project.

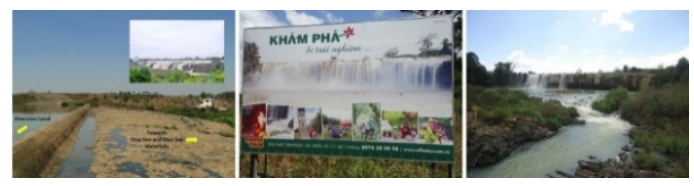

Figure 1. Se Re Pok Project, Buon Me Thuot Province, with Dray Nur Waterfalls Before, and Now.

The inset photograph in Figure 1 shows the natural drop in elevation of approximately 3 meters as it once appeared prior to construction. The diversion canal shows a weir height substantially larger than the natural drop. This drastically reduces the water flowing towards the Dray Nur and Dray Sap Waterfalls. Similar constructions across many rivers have caused waterfalls to dry up due to the manually increased weir height upstream causing the downstream ecology to deteriorate rapidly.

Hydropower development, therefore, must be viewed from an integrated perspective that combines the ecology, the environment, and the energy needs of a region. An integrated view allows the development of technologies that aid in building healthy regenerative ecosystems. In the Lam Dong Province of Vietnam, for example, there are many possibilities to augment existing weir structures (both small and large weir structures), with modular power harvesting weirs. This has the potential for boosting the regional economy and foster a self-sustaining regenerative ecology. Figure 2 conceptually illustrates this concept using modular power harvesting weirs as a means to capture the potential energy.

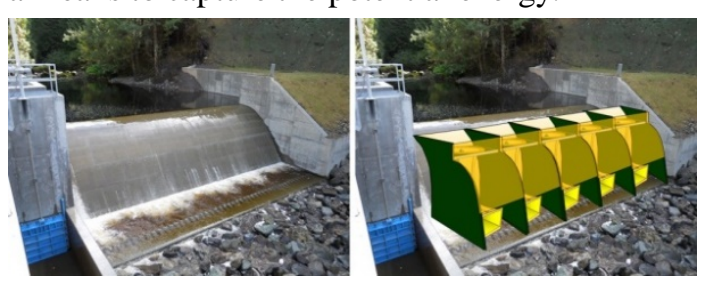

Figure 2. (Left) A human engineered Weir, (Right) A human engineered power harvesting Weir.

As scientists and engineers, our perceptions of future hydropower development must be explored in ways that use current NASA Earth Science data to fully characterize those regions which have been seriously threatened, and find ways to regenerate the ecology through use of new and novel ideas that preserve both upstream and downstream ecology. The Mekong Delta Plan, which outlines a strategy over a 100-year horizon, provides the motivation to conduct such an assessment and to create a roadmap for sustainable hydropower development in the Delta Region. To meet such a grand vision that extends into the $22^{\text {nd }}$ century, our perceptions of a technology that stimulates ecological recovery in places whichare most effected must take precedence starting now, and for regenerative ecosystems to propagate towards larger ecosystems with an abundance of renewable natural resources in the future. References [1][10] are included for a baseline background on this project.

\section{TECHNOLOGY AND ECOLOGY}

The purpose of this paper is three-fold: a) to emphasize the in-depth systems engineering approach that was undertaken in transforming a 
hydropower design concept into two prototypes with the intent to transform a historic drop station into a small-hydro demonstration pilot-plant; b) the systems engineering path that encompassed a holistic approach by considering the environment as a whole in which the technology would reside, with a clear understanding of the short-term and longer-term benefits and impact of this technology on agriculture, and in particular the efficient use of water resources in Southern New Mexico and the region; and c) to create opportunities for applications in Vietnam, Cambodia, Laos and neighboring countries where this technology might be useful and with the goal to sow the seeds for ecological recovery, increase environmental awareness, and raise the overall societal consciousness towards effective use of energy.

Innovative design in areas of energy harvesting requires the combined understanding of the ecosystem and the augmenting technology, thorough research, design, and holistic integration within real-world self-sustaining regenerative ecosystems. Design and research are inseparable. Products that are optimized through a continuous cycle of research, design, test and evaluation hold the greatest potential for worldwide use and commercialization success.

\subsection{Drop 8 Station}

Built in the early 1900's, the Drop 8 Station (Figure 3) is a steel and concrete structure that has two vertical drops approximately 2 meters in height that allow irrigation water to drop and flow downstream. Concrete embankments prevent soil erosion. Figure 3 shows the Drop 8 Station as it appears each year during the irrigation season between May through August. Irrigation flow that enters through arc-gate controlled inlets, passes through a reservoir with two circular orifice vertical drops, and has a gate controlled opening at the front to allow larger flows towards the tailrace. Located nearby the local utility, the possibility for grid connection offers sufficient incentives to transform the drop site to a smallhydro plant.

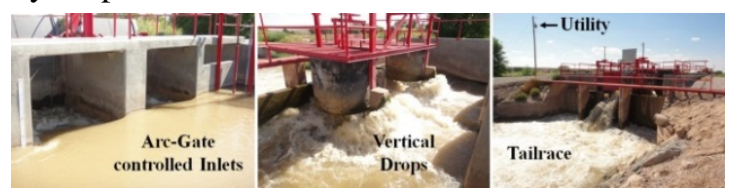

Figure 3. Drop 8 Station

\subsection{Concept Overview}

Constrained by the historic nature of the drop site, and the State and Federal environmental protection regulations that prohibit structural changes, the challenge was to conceive a freestanding harvester structure that would have no load bearing impact on the historic structure, and could be deployed with no structural modifications. The technology had to be customfitted within the existing structure, while simultaneously meeting an economic criteria for cost-effectiveness and a criteria for minimal intrusion into the natural environment. The system had to be cost-beneficial to manufacture, affordable, efficient and be easily deployable. The system had to satisfy all other intangible attributes that leave a negligible footprint on the ecology.

From a technical and manufacturing viewpoint the tangible attributes give precise meaning to the performance and costeffectiveness that justify technical feasibility and economic viability. The intangible attributes, however, are ones that make the technology to coexist in the ecology and act in ways to reinvigorate and regenerate the ecology. For this, the technology must obviously be non-polluting (i.e., materials used in fabricating do not add pollution), be elegant, and must blend-in with the environment creating an ambience and appeal that bridges the gap between the ecology and the sustainable energy needs of the society. It is profoundly mindful and considerate to leave the ecology the same way as when we found it for

Trang 134 
future generations to benefit. This adds to our overall understanding of sustainability and the implications of discovering revolutionary hydropower technologies. So, what could such a technology be that meets these criteria for energy use and ecological preservation? This would be the natural question to ask in light of technological advances needed in the Mekong Delta Region over the next 100 year horizon.

Designed as a run-of-river technology it is important to note that there is no impoundment required in low-head hydro development. Gravity-fed water is allowed to run freely, except for a momentary pressure drop by which energy is harvested. As such, the technology has no impact on land use making it environmentally benign.

\subsection{Conceptual Design}

The conceptual design and subsequent prototype discussed in this paper are the outcome of the Hydropower Energy Resource (HyPER) harvester Project funded by the U.S. Department of Energy to research and develop a novel hydropower technology. Although the site has a estimated hydropower potential of approximately $140 \mathrm{~kW}$, a $20 \mathrm{~kW}$ plant with two $10 \mathrm{~kW}$ harvesters was targeted as a proof-of-concept. The harvester is designed to be custom-fitted to a unique drop site at the Elephant Butte Irrigation District Drop 8 Station in Southern New. The unique characteristics of the drop site has provided the best opportunity to optimize the performance of a vertical-axis Kaplan-type turbine suitable for lowhead small-hydro plant development. The objectives of the HyPER Project were to show both technical feasibility and economic viability. With modularity and ease of deployment considered as the key attributes, a design concept illustrated in Figure 3 shows modular components for a harvester along with a conceptual implementation that mimics the shape of conventional large-scale Kaplan turbine.
Referring to Figure 4, the components of the harvester are: 1) the turbine module which has an impeller and the required electromechanical power generating and instrumentation components enclosed within a submarine, and 2) a discharge elbow module and a draft tube which extends the discharge to a length that optimizes diffusion. The discharge elbow and draft tube, which collectively optimize the fluid motion for effective diffusion, could be combined as one module under space constraints. As such, it is easy to perceive a novel hydropower technology having just two modules, namely, a fully integrated and instrumented turbine-generator module, and a discharge module.

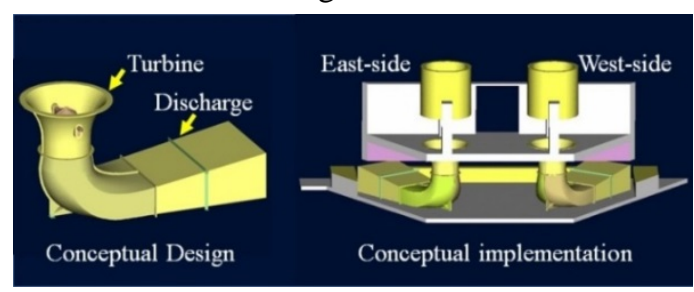

Figure 4. Effectiveness of modular elements of the low-head hydropower harvester

The conceptual design made deployment to appear minimally intrusive due to the selfsupporting ability of the harvester. Modular elements fabricated with light weight and highly durable Carbon-composite materials created a plug-\&-play architecture for easy deployment. The modules could be easily transported and deployed. Modularity and a 3-step conceptual installation process shown in Figure 5 appeared to minimize installation time, pointing to possibilities for significantly reducing the cost of developing micro-, mini-, and small-hydro plants.

Modularity and scalability are the principal attributes of the harvester that make it costeffective. The technology had to be reliable, easy to operate and maintain. Because no construction would be required, the LCOE would be at a minimum. These attributes taken collectively suggested that the installed capital cost (\$/Watt) 
must be a minimum in order for the Levelized Cost Of Engineering (LCOE, $\$ / \mathrm{kWhr}$ ) to be at a minimum. With present cost of hydropower at $\$ 2.50 /$ Watt or higher, the technology, therefore, had to be low-cost and significantly less than $\$ 2.00 /$ Watt in production runs in order to meet a U.S. DOE criteria of less than $\$ 0.05 / \mathrm{kWHr}$.

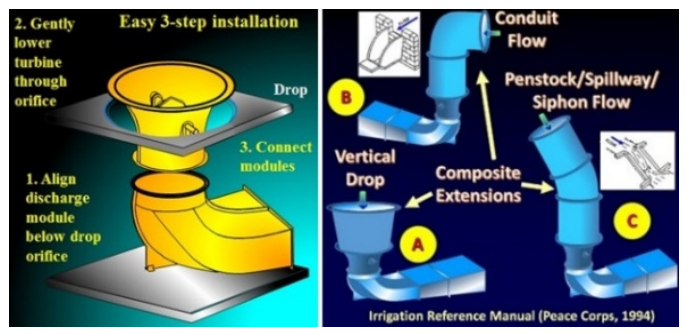

Figure 5. Modularity and ease of deployment

There is no doubt that the cost of generating equipment including the alternator and associated power electronics constitute the major portion of the harvester cost. Research has shown possibilities for reducing the cost by employing axial-flux permanent magnet alternators. Discussions with manufacturers has indicated the possibilities for $\$ 0.70 /$ Watt for the alternator and $\$ 0.30 /$ Watt for power conditioning equipment. It is important to mention in passing that a criteria of \$1.00/Watt of installed capital cost has the potential for lowering the LCOE to less than two cents per $\mathrm{kWHr}$, i.e., $\$ 0.02 / \mathrm{kWhr}$. With advances in Permanent Magnet Alternator technologies it is conceivable that low-speed axial-flux alternators with associated power electronics can be built at low cost, to replace the larger diameter radial-flux alternators that are high-cost and hard to implement.

\subsection{Other Drop Applications}

The uniqueness of Drop 8 does not limit the application of the HyPER harvester to any one specific type of drop site. In fact, the advantages of this technology are the simplicity in design and the ease of installation as a conventional Kaplantype which ensures the potential for highest power harvesting efficiency. Because there is no impoundment, the technology is ecologically attractive. The concept developed for Drop 8 Station is adaptable for other types of drop sites requiring conduit flow to channel the water through the turbine. As illustrated in Figure 5, the shape and form of the harvester can conform to space constraints while maintaining the best flow characteristics through the turbine cavity. Figure $5 \mathrm{~A}$ is similar to Drop 8, but with additional space between orifice and harvester requiring an extension of truncated-cone shape fabricated using composite materials. This extension can be dropped into the orifice and connected by flange couplings to the harvester below. Figure 5B shows possibilities for drop through conduit flow where cylindrical conduits (flexible tubes, in their simplest form) could serve as intake to the turbines. Figure 5C shows possibilities for spillway, penstock, and siphon flow that makes use of conduit extensions to channel the flow into the turbines.

\subsection{Shape Significance}

The shape and form of the harvesting system is extremely important because it creates an optimal flow-path while minimizing losses. Figure 6 illustrates the shape transformation between the inlet and outlet of the harvester.

Beginning from the Venturi-turbine inlet, the first change is from a hyperboloid-shape to a cylindrical-shape around the full height of the impeller. By maintaining a gap $<5 \mathrm{~mm}$ between the blade-tip and the inner wall of the cylinder the cylindrical-shape minimizes head-loss. As the fluid exits the turbine through the impeller, it expands, forming the shape of a truncated cone.From a past reference prepared in the 1940's, at typical low-head velocities, the experimentally-observed divergent cone-angle is between 20-30 degrees.

The expanding fluid at the edge of the impeller nozzle has a high tangential velocity caused by 
increased pressure and the swirl velocity in fluid motion. By constraining the expanded cone to approximately 10 degrees there is a two-fold gain in the total amount of average kinetic energy that can be recovered. For this, the swirling velocity must be converted to an axial velocity such that a maximum amount of kinetic energy can be harvested through diffusion during the period when fluid motion decelerates towards normal flow at the entry to the tailrace. A shape transformation in the diffuser (the discharge tube) converts rotational velocity to linear velocity. This creates a suction pressure causing the impeller to increase in speed. This qualitative understanding helps in interpreting fluid dynamic simulations.

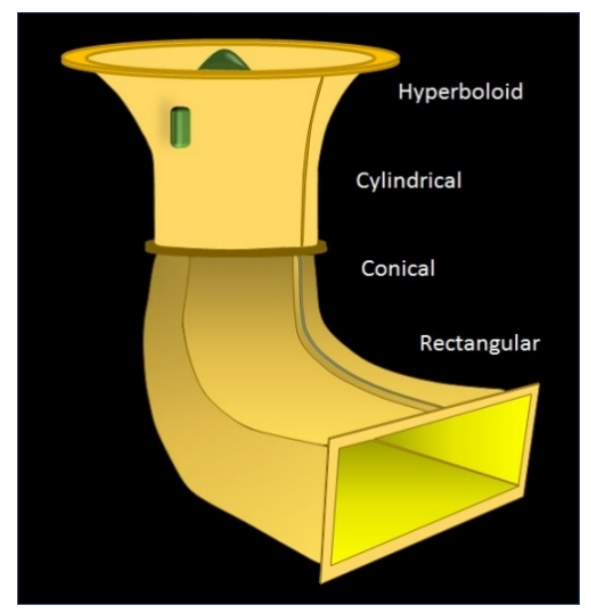

Figure 6. Optimum shape of turbine

\subsection{Simulated Fluid Motion}

Based on a 3D model of the Drop 8 Station and a baseline concept design, simulations using the ANSYS $®$ computational fluid dynamics software aided in optimizing the design characteristics of the $10 \mathrm{~kW}$ harvester. Streamline flow pattern in Figures 7 and 8 under normal flow conditions, with $1.5 \mathrm{~m}$ head and discharge about $6.5 \mathrm{~m} 3 / \mathrm{s}$, (approx. $230 \mathrm{cfs}$ ) provide sufficient axial and rotational velocity components, and pressure drop to create high enough torque at low speeds.

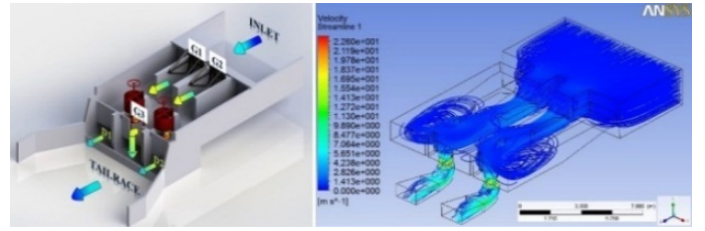

Figure 7. CFD simulation of flow through Drop 8 Station

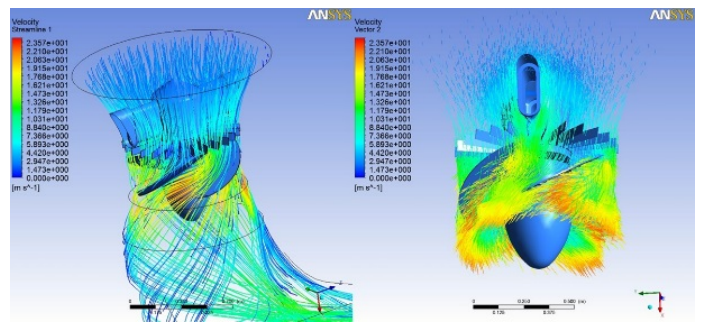

Figure 8. CFD simulation illustrating swirl velocity

The streamline flows vividly describe the flow path from the inlet to the outlet. It is seen that as the fluid passes through the drops the linear velocity at the inlet is transformed to a swirl velocity through the drops.

\subsection{Fluid Dynamic Performance}

Upon emerging from the drops the swirl velocity is transformed back to linear velocity. This, as described previously, aids in recovering the kinetic energy due to diffusion. The pressure drop across the impeller causes the discharge to return to atmospheric pressure. Through extensive CFD simulations it is found that a rectangular cross-section satisfactorily transforms the swirl velocity to axial velocity. Figure 9 shows the fluid dynamic performance characteristics for the harvester and confirms the shape transformation from a hyperboloid to a cone and then to a rectangular cross-section as scalable. The shape, therefore, can be optimized for the highest efficiency at any given site.

\subsection{Performance Characteristics}

CFD studies aided significantly in summarizing the design characteristics of a $10 \mathrm{~kW}$ harvester. The two critical parameters which 
optimize the turbine performance are: a) the impeller hub-to-tip ratio defines the surface area of blades to react to a vertical fluid force, causing a volumetric pressure drop across the impeller

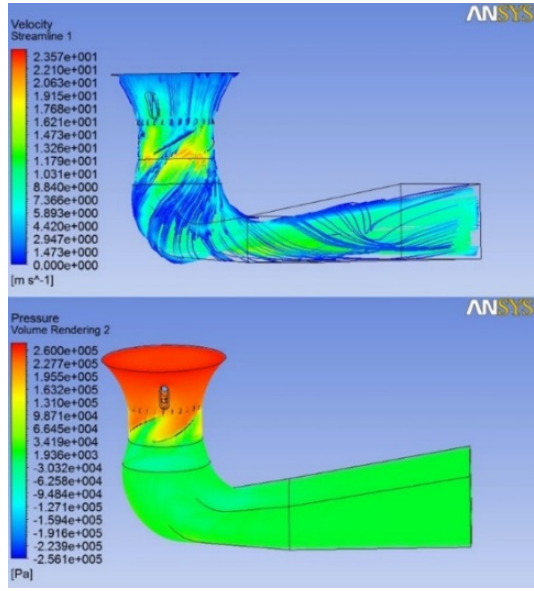

Figure 9. CFD simulation showing streamline flow velocity and pressure for $2 \mathrm{~m}$ head

blades, and b) the blade angle which creates the maximum tangential velocity that maximizes the torque. CFD simulation in Figure 10 shows the pressure differential between the top and bottom surfaces of a $30^{\circ}$ fixed pitch, 4-blade impeller and the Venturi turbine. Appendix includes supplementary information pertaining to the blade design and thrust bearings selection.

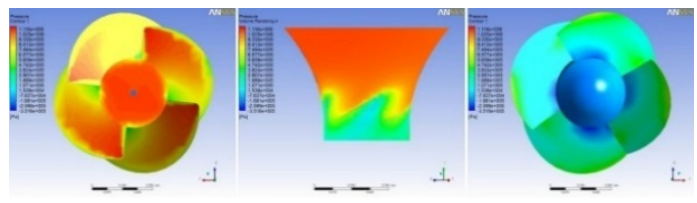

Figure 10. CFD simulation pressure differential across the impeller

\subsection{Prototype Fabrication}

An important objective of the HyPER project was to develop a manufacturing process to enable rapid manufacturing and assembly of harvesters at the least cost. By adopting an additive manufacturing technology, the first step in the manufacturing was to fabricate molds that allow Carbon-composite materials and Fiberglass layers to be placed in layers and bonded in epoxy to create half-section moldings of the prototypes. This included molds for the Venturi, the draft tube, and the submarine. The same molds could be used for manufacturing five or more prototypes, thereby, considerably reducing the average cost of manufacturing each $10 \mathrm{~kW}$ unit. The graphic in Figure 11 shows mirror-finished turbine and discharge half-molds. The molds have a core of Styrofoam ${ }^{\circledR}$ sheets cut in the desired shape and held in place using wood-glue and epoxy-resin to create a rigid and smooth mirror-finished surface. Such molds are required to produce turbine castings using additive manufacturing techniques.

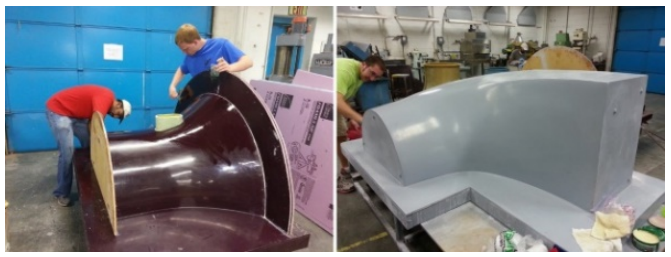

Figure 11. Mirror-finishing half-molds of Venturi-turbine and discharge elbow

Various stages of the manufacturing process shown in Figure 12 included fabricating molds of the Venturi-turbine, the discharge tube and the submarine, tailoring to optimize the use of Kevlar® fabric, creating turbine moldings, crafting a 4-blade Carbon-composite impeller, and a mockup of the two self-standing harvesting systems.

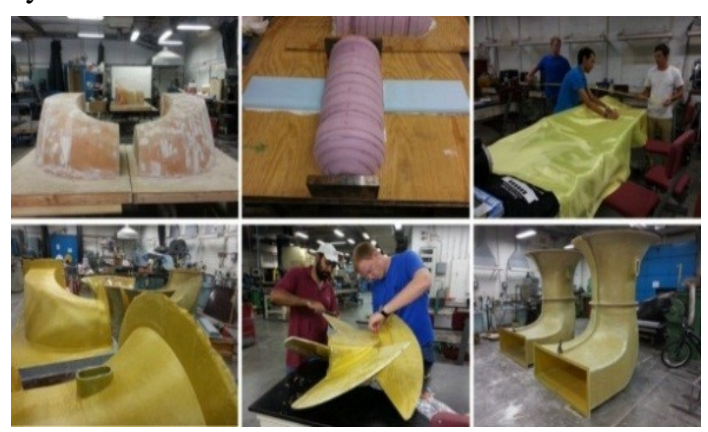

Figure 12. Various stages in manufacturing

Figure 13 is a mosaic of the key components in the turbine assembly. Beginning with a preassembled molding of one half of the turbine 
casing and submarine in (1), an alternator coupled to the impeller assembly including the thrust bearing in (2) is placed inside the submarine in (3). Generator and impeller shaft coupling and thrust bearing are secured inside the submarine in (4). Instrumentation to sense inlet and outlet pressure, 3D displacement along with voltage and current sensors for generated power is shown in (5) and (6). In (7) and (8) the other half of the submarine casingand the turbine moldingare thenplaced and secured by bolts. The completed turbine prototype is shown in (9). These demonstrate ease of assembly in manufacturing.

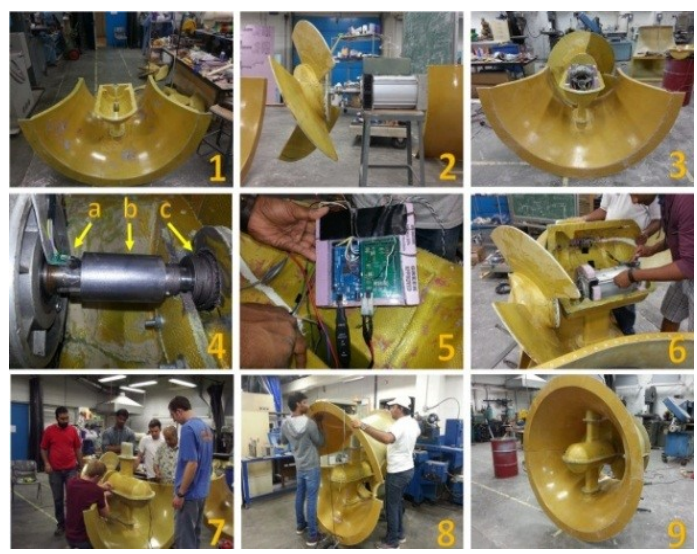

Figure 13. 10kW Harvester prototype assembly

Figures 14 shows a fully assembled turbine and discharge tube at MTEC, the NMSU manufacturing technology center, prior to transportation to the EBID Drop 8 Station.

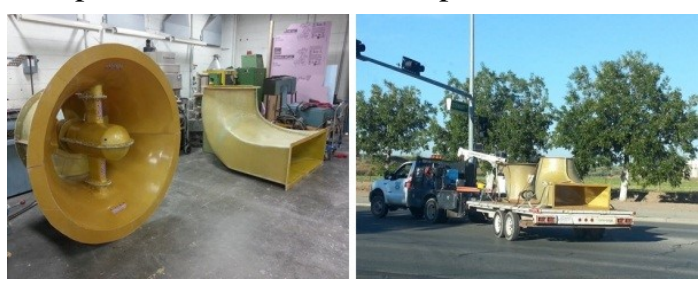

Figure 14. Fully assembled 10kW harvester enroute to Drop 8 Station

Figures 15 and 16 highlight the close similarity between actual field implementation of two harvester units and the perceived implementation at the beginning of the
project.The remarkably short implementation time shows how quickly a site can be transformed to a hydropower plant.

Figure 17, picture on left shows the Southside view of two harvesters implemented at the Drop 8 Station since October 2014 during the dry season. Picture to the right shows subsequent flows through the drop following water release in the irrigation canal.

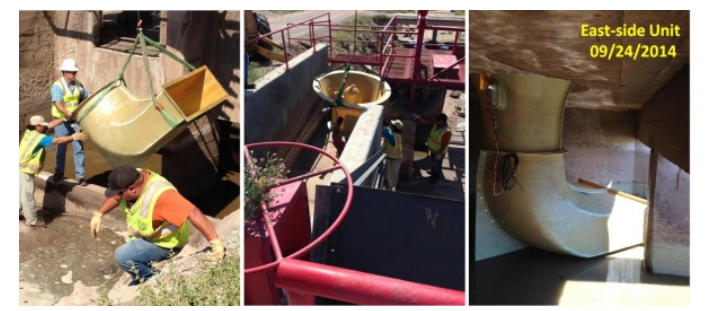

Figure 15. Placement and alignment of modules for East-side harvester installation $\sim 1$ hour

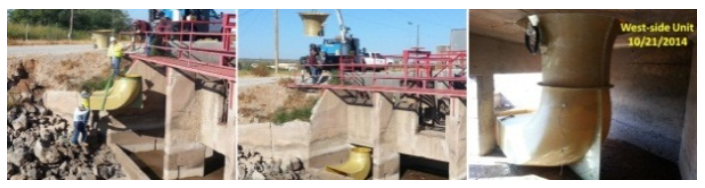

Figure 16. Placement and alignment of modules for West-side harvester installation $\sim 1$ hour

The graphic shows flows and the effective head at the station during normal conditions giving a perception for generating capacity.

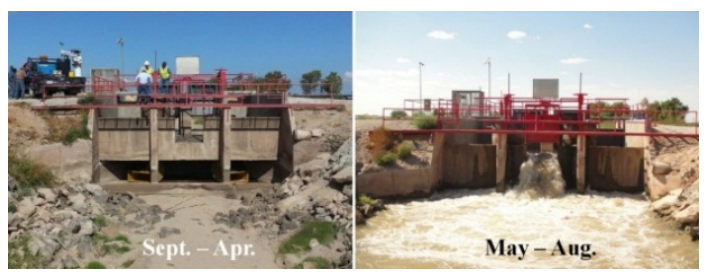

Figure 17. Installed units at Drop 8 Station

\section{CONCLUSIONS}

The manufacture and deployment of two $10 \mathrm{~kW}$ harvester prototypes serve to demonstrate the low cost of developing low-head hydropower plants. Simplicity in design and packaging of elements leads to substantial cost reductions in manufacturing and assembling hydropower harvesters. A plug-and-play modular architecture 
makes the installation easy and helps in creating a robust market for a new generation of hydropower harvesting systems. The self-supporting structure lowers the LCOE thereby making it an affordable technology. While the harvester awaits testing at the irrigation site, the fabrication, assembly and deployment of the harvesters highlight the ease of manufacturing and developing micro- and smallhydro plants. With strong commercialization possibilities, the HyPER harvester holds promise towards its expanded use worldwide for hydropower generation from low-head water resources.

\section{ACKNOWLEDGEMENTS}

The first two authors thank the U.S. Department of Energy for supporting the research and development under Contract DE-EE0005411, titled "The HyPER Project".

The first and third authors thank the Fulbright Foundation for their respective 6month fellowships, the first author as a 2012 U.S. Scholar in Vietnam and third author as a 2013 Vietnam Scholar in the U.S., respectively. Their individual experiences and mutual understanding of hydropower technology development has been transformative in building a common understanding of the concerns towards the environment, the ecology and the effective use of energy from the vast low-head hydropower resources in Vietnam. The views expressed strongly reflect the Fulbright vision to bridge the educational, cultural and social understanding between Nations and bring technological advances in Nations towards a Greener and more energy conscious society.

\section{APPENDIX}

Guide-vanes: Although the purpose of guide-vanes is to allow the water to impinge on the leading edge of the blades at maximum velocity, the use of guide-vanes in harvesters for irrigation canal is not recommended as it may clog the turbine inlet. However, where permissible, a turbine assembly with guide-vanes could be as shown in Figure A.1.

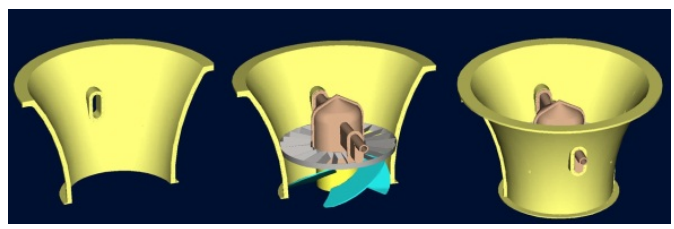

Figure A.1. Ring-type guide-vane for effective fluid motion towards impeller

Trash Guards: While several preventive approaches may be conceived, the adoption of high strength Carbon-composite materials that add to the durability of the turbine structure is significant towards withstanding the harsh environment of irrigation waters. Fiberglass reinforced with Kevlar® offers extraordinary resistance to sand, and rocks and has the ability to withstand the pressure. Floating debris, however, such as plastic bottles and large pieces of dried natural vegetation must be blocked at the inlet to prevent clogging the turbine. Figure A.2 illustrates a possibility considered for the Drop 8 Station.

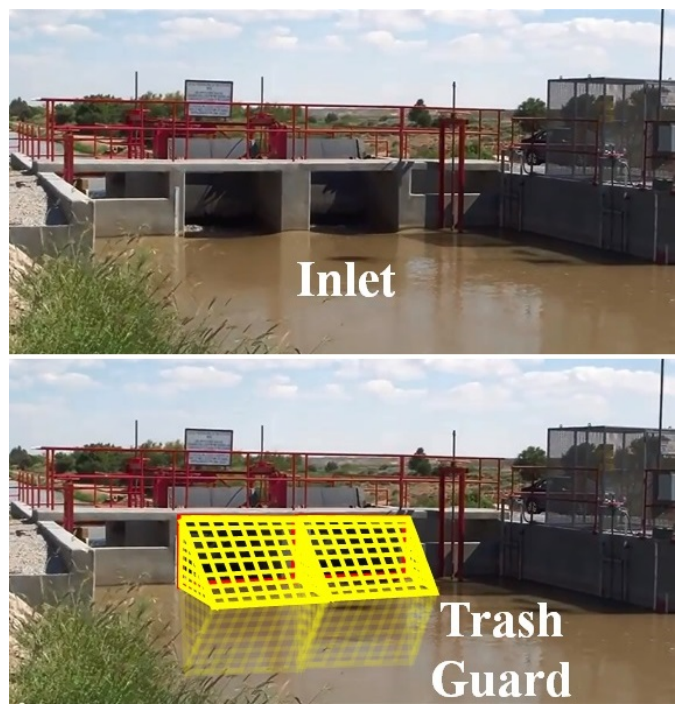

Figure A.2. Trash mitigation at Drop 8 Station 


\section{Khai thác nguồn thủy năng cột áp thấp: thiết kế và chế tạo hệ thống phát thủy điện}

- Nadipuram R. Prasad

- Satish J. Ranade

New Mexico State University, Las Cruces, New Mexico, USA.

- Nguyễn Hũu Phúc

Trường Đại học Bách Khoa, ĐHQG-HCM, Việt Nam.

\section{TÓM TÁ́T}

Bài báo trình bày việc thiết kế và chế tạo một hệ phát thủy điện trên quan điểm đặt nặng vấn đề sinh thái và môi trường. Dựa theo các tiêu chuẩn hướng dẫn của NEPA về bảo vệ môi trường, ý tưởng thiết kế bao gồm một cấu trúc kiểu module tự ổn định với hệ thống máy phát-turbine trục đứng với các đặc điểm: a) khối lượng nhỏ dùng vật liệu composite sợi carbon và thủy tinh, b) dễ dàng chế tạo, lắp đặt và dùng các bộ phận cơ-điện sãn có trong sản xuất năng lượng. Phần mềm động lực học lưu chất ANSYS được dùng để tối ưu hóa các đặc tính dòng chảy của turbine. Trong bài báo giới thiệu một nguyên mẫu hệ máy phát cột nước thấp 10-kW được chế tạo kiểu module, dễ nâng cấp công suất, với 4 cánh quạt có góc nghiêng cố định. Công nghệ phát điện này thích hợp với các hệ thống tưới tiêu thủy lợi cột nước thấp với các công trình xây dựng đang tồn tại, và với các đập tràn trên các dòng sông nhỏ trên thế giới.

Từ khóa: động lực học tính toán dòng chảy, hệ sản xuất năng lượng, turbine Venturi cột nước thấp, cánh quạt turbin.

\section{REFERENCES}

[1]. Nadipuram R. Prasad, Satish J. Ranade, Hydropower Energy Resource (HyPER) Harvester; Department Of Energy 2014 Water Power Program Peer Review Compiled Presentations - HydroPower Technologies, Washington Feb 25-28, 2014.

[2]. Schweiger, F. and Gregory, J. ; Developments in the Design of Kaplan turbines; Water Power \& Dam Construction, Vol. 39, \#11, Nov. 1987, pp 16-20.
[3]. Sadek, R. and Sinbel, M. A.; Water Turbines and Dimensional Analysis; Water Power Vol. 12, \#10, Oct. 1960, pp 381-389.

[4]. "Micro-hydropower: Reviewing an old concept" DOE/ET/01752-1, January 1979 http://hydropower.inel.gov/techtransfer/pdfs/ doe-et-01752-1.pdf.

[5]. Boucher, P. J. "Chutes-de-la-Chaudiere: optimizing hydraulic potential, enhancing natural beauty" Hydro Review, Vol. XX, \#4, July 2001, pp. 76-80. 
[6]. Gordon, J. L. "Turbine selection for small low-head hydro developments", Unknown publishing date.

[7]. Kai-Wern Ng, Wei-Haur Lam, Khai-Ching Ng.; 2002-2012: 10 Years of Research Progress in Horizontal-Axis Marine Current Turbines; Energies 2013, 6, 1497-1526;

[8]. Ram Prasad, Phuc Huu Nguyen; Hydropower Energy Recovery (HyPER) from Water-Flow Systems in Vietnam, Proceedings of the 10th IEEE International Power and Energy
Conference (IPEC 2012- Ho Chi Minh City); HoChiMinh City Dec 12-13, 2012.

[9]. John F. Wendt (Ed.) and al.; An introduction to Computational Fluid Dynamics, Third Edition, Springer- Verlag 2009.

[10].Nadipuram R. Prasad, Satish J. Ranade, PhucHuu Nguyen, Low-Head Hydropower Energy Resource Harvesting: Estimation of Maximum Harvestable Power, Paper submitted to ISEE 2015, Oct 2015 HoChiMinh City, VietNam. 